\title{
Antibacterial Effect Of Kaempferia Galanga $L$ Extract On Lactobacillus Acidophilus -In Vitro
}

\author{
Josi Saraswati, Annisa Septalita, Arini Bovita. N \\ Faculty of Dentistry, Prof. Dr. Moestopo University, Jakarta
}

\begin{abstract}
Introduction: Lactobacillus acidophilus is one of the bacteria causes dental caries. The previous study has shown that Kaempferia galanga extract has a potential to inhibit the growth of Lactobacillus acidophilus.

Objective: To determine the antibacterial effect of Kaempferia galanga extract to Lactobacillus acidophilus.

Methods:Kaempferia galanga is extracted in 3 different solvents:dichlormethane, ethanol, and aquades. For each solvent, $0.2 \mu \mathrm{l}$ Kaempferia galanga extractdroped into $6 \mathrm{~mm}$ steril paper dics. $0.1 \mathrm{ml}$ Lactobacillus acidophilus inoculated on MRS agar. Each disc contains extract were impragnated into the agar media, then incubated at $37^{\circ} \mathrm{C}$ for 24 hours, and inhibition zone measured.

Results: Mean scores of Kaempferia galanga extract in 3 different solvents are: Kaempferia galanga (dichlormethane) is 1.6400; Kaempferia galanga (ethanol) is 1.7440; Kaempferia galanga extract is 1.6600; boiled Kaempferia galanga is 1.7000 . Using Mann-Whitney Test, the results are: negative controls have no inhibition effect on Lactobacillus acidophilus compaired to Kaempferia galanga extract, comparation of those 4 Kaempferia galangal treatments shows no significant difference, those 4 Kaempferia galanga treatments compaired to erythromycin antibacterial effect shows significant difference, otherwise 4 Kaempferia galanga treatments compaired to penicillin shows no significant difference except Kaempferia galanga (ethanol).

Conclusions: Kaempferia galanga extract can kill Lactobacillus acidophilus. Inhibition effect of Kaempferia galanga extract has no significant difference to penicillin but lower inhibition effect than erythromycin. The Kaempferia galanga extracts showed better antibacterial activity than penicillin.
\end{abstract}

Key Words : Antibacterial, Kaempferia galanga L, Bacteria, Dental caries.

Korespondensi : drg. Josi Saraswati, Faculty of Dentistry, Prof. Dr. Moestopo University, Jl. Bintaro Permai Raya no 3,

South Jakarta, Indonesia 12330

email : jossie_bochie@hotmail.com

\section{PREFACE}

Dental caries is one of many types of caries. Dental caries affects different parts of the teeth: enamel, dentin or cementum; in the crown or the root of the tooth. Nearly all contain bacteria such as streptococcus mutans and lactobacillus. ${ }^{[1]}$ Tooth decay is caused by certain types of acid-producing bacteria (specifically Lactobacillus species, Streptococcus mutans, and Actinomyces species) which cause damage in the presence of fermentable carbohydrates such as sucrose, fructose, and glucose. The resulting high levels of acidity from lactic acid in the mouth affect teeth because a tooth's special mineral content causes it to be sensitive to low $\mathrm{pH}^{[2]}$. In recent study, the researcher found a number of Lactobacillus in oral mucosa that made these bacteria as the causing factor specific microbial in dental caries ${ }^{[3]}$. If the development of Lactobacillus can be inhibited, the forming proccess of caries can be prevented

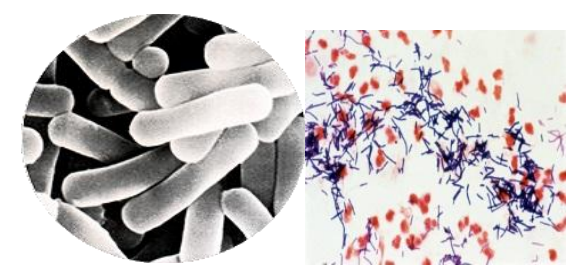

Figure 1. Lactobacillus acidophilus ${ }^{[4][5]}$

There are so many ways can be used by people to prevent the development of Lactobacillus in oral, such as using 
penicillin, erythromycin, ethanol and dichlormethane. But due to the negative side effect of these substance, the alternative to prevent the development of Lactobacillus acidophilus was found using herbal extract, in this case we choose Kaempferia galanga. According to some studies, Kaempferia galangal contains atsiri oil which has antibacterial effect. ${ }^{[6],[7]}$

Kaempferia galanga is a herbal perennial plant with a collection of rosset shaped leaves close to the soil surface, which roots have rhizome shape (Sudarsono et al.,1996). Kaempferia galanga is included in the

Family of kingdom : Plantae,

Division : Spermatophyta,

Sub Division : Angiospermae,

Class : Monocotyledoneae,

Ordo : Zingiberales,

Family : Zingiberaceae,

Genus : Kaempferia. ${ }^{[6]}$

Kaempferia galanga has often used as traditional medicine, fitofarmaka, cosmetic industry, foods and drinks seasoning, spices and also the mixture ingridients in cigarettes and kretek cigarettes industry. Empirically, this Kaempferia galanga is also use to boost appetite, elixir, eliminate phlegm, warm the body, prevent free radical as one of the cause of early aging, relief cough infection and stomachache, cure disentri, for making tonicum, slimming medicine, helping chase away gas from the stomach and expectorant, last but not least commonly used as the concoction to stay young and also as one of the ingredients of healthy drinks ${ }^{[8][9]}$

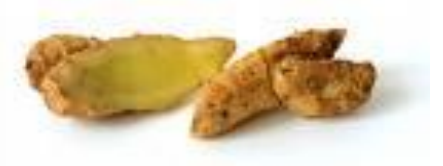

Figure 2.Kaempferiagalanga $a^{[10]}$

Kusmaningati (1994) reported that Kaempferiagalanga contain kaempferol a kind of flavonoid, kaempferid (kaempferol4-metil eter) has the function as antibacterial and antioxidant, eucalyptol, borneol which has also function as antibacterial as well as aromatic, etilester p methoxycinnamid acid, sinamil aldehid and pentadekana.Kaempferia galanga has the characteristic of easing the pain to toothache, headache, rheumatic, carminativum, to warm the body and stimulant (Sudarsono et al.,1996). ${ }^{[6]}$

Kaempferia galanga contains atsiri oil (Dirjen Pengawasan Obat dan Makanan, 1981; Dharma, 1987), that the main component is etilester $p$-methoxycinnamic acid 3\% (Chairul et al., 1994) . This etilester $p$-methoxycinnamic acid $3 \%$ has antioxidant function (Windono et al., 1994).Kaempferia galanga contains atsiri oil which is form of monoterpenoid, sesquiterpenoid, borneol, camphene, $\mathrm{p}$ methoxy sterene, sineol, etilalkohol. (Sudarsono et al., 1996). According to Harris (1990) atsiri oil is various kind of a vagetables oil which contains a lot of aroma and evaporate easily. These elements unite with glucose in chloroplast create glucoside which distributed to all parts of the plant. In that place specially flowers, plants produce a kind of enzyme which attack glucoside so at the end atsiri oil has been created. ${ }^{[6]}$ This atsiri oil has a wide spectrum which is active toward bacteri and fungus with a strong activity. [11]

The above empirically and laboratories studies indicates that Kaempferia galanga might be useful for preventing dental cavities. Based on the character of selective toxity, here is antibacterial which can kill the bacteria known as "bacteriosid". In this study, we will discover whether Kaempferia galanga extract affects the growth of Lactobacillus acidophilus, in the IN VITRO method. 


\section{MATERIALS AND METHODS}

\section{Microorganisms}

Lactobacillus acidophilus was mainly used in the assay of the antibacterial activity of Kaempferiagalanga extracts.

\section{The Study Design}

Kaempferia galanga extract

Lactobacillus acidophilus
before treatment

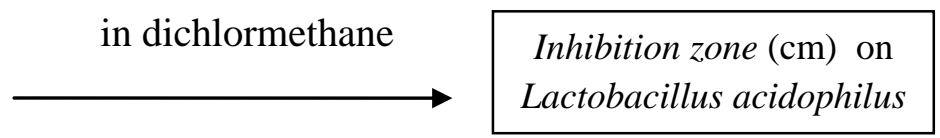

Kaempferia galanga extract

Lactobacillus acidophilus
before treatment

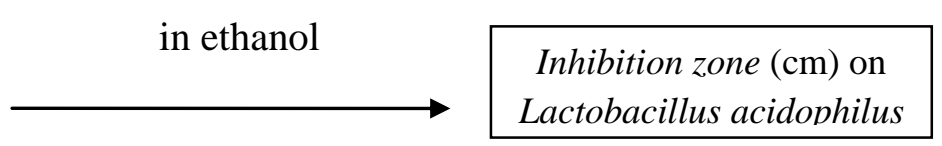
Lactobacillus acidophilus before treatment
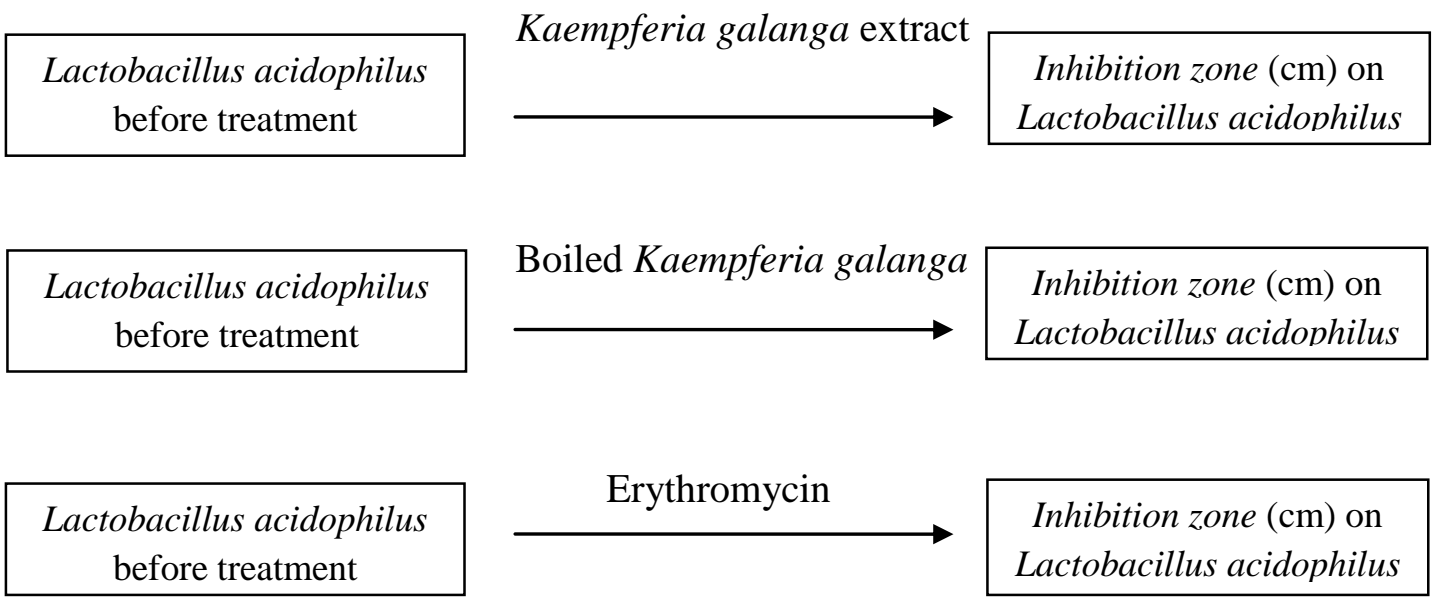
Lactobacillus acidophilus before treatment

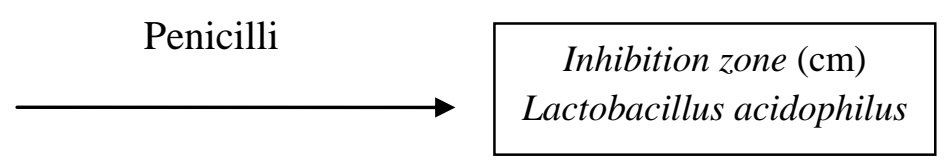

Figure 3. The Study Design

\section{Preparation of Kaempferiagalanga extract in Dichlormethane}

$50 \mathrm{gr}$ Kaempferia galangal extract placed in Erlenmeyer $300 \mathrm{ml}$ and added $150 \mathrm{ml}$ dichlormethane for 24 hours. Then, siped with the Whatman filter paper to get precipitate. This precipitate can be dried using rotary evaporator, then diluted with 1 $\mathrm{ml}$ dichlormethane.

\section{Preparation of Kaempferia galangaExtract in Ethanol}

50 gr Kaempferia galangal extract placed in Erlenmeyer $300 \mathrm{ml}$ and added $150 \mathrm{ml}$ ethanol for 24 hours. Then, siped with the Whatman filter paper to get precipitate. This precipitate can be dried using rotary evaporator, then diluted with 1 $\mathrm{ml}$ ethanol. 


\section{Preparation of Kaempferia galanga Extract}

Rasped 100 gr Kaempferia galanga to small pieces and press it, after that siped with the Whatman filter paper till we get 10 $\mathrm{ml}$ extract and dregs.

\section{Preparation of Boiled Kaempferia galanga}

100 gr Kaempferia galanga added with $250 \mathrm{ml}$ aquades then boiled it. Then, siped with the Whatman filter paper till we get 15 $\mathrm{ml}$ extract and dregs.

\section{Preparation of Media Culture}

Disolved each media of MRS broth and agar (54.2 $\mathrm{g}$ each) in $1000 \mathrm{ml}$ distilled water in erlenmeyer and then it is heated in $100{ }^{\circ} \mathrm{C}$ and stirred on AM4 Multipositioning Magnetic Hotplate Stirer until perfectly disolved. Then, sterillized it using autoclave $\left(121{ }^{\circ} \mathrm{C} ; 1.5 \mathrm{~atm}\right)$ for 20 minutes.

\section{Preparation of Inoculum Bacteria}

Lactobacillus acidophilus in slanted agar MRS be inoculated in the media of 9 $\mathrm{ml}$ MRS broth in the experiment tube. And then, it is incubated in the temperature of $37{ }^{\circ} \mathrm{C}$ for 24 hours to determine the number of cell amounting 108 by finding the absorbance number amounting 0,5 with the length of the wave 650 (Mc Farland Standard) using spectrophotometer (Thermo Spectonic Helios $\alpha$ ).

\section{The Experimental Method}

Kaempferia galanga is extracted in 3 different solvents:dichlormethane, ethanol, and aquades. For each solvent, $0.2 \mu \mathrm{l}$ Kaempferia galanga extractdroped into 6 $\mathrm{mm}$ steril paper dics. $0.1 \mathrm{ml}$ Lactobacillus acidophilus inoculated on MRS agar. Each disc contains extract were impregnated into the agar media, then incubated at $37^{\circ} \mathrm{C}$ for 24 hours, and inhibition zone measured.

\section{Statistical Analysis}

The inhibition zone of Kaempferia galanga extracts and boiled, Kaempferia galanga extracts in dichlormethane and in etanolwere statistically analyzed by calculating means and standard deviation. Differences between means of the treatment and control groups were evaluated by Mann-Whitney Test.The data in our research is interval. Interval data should be analyzed by parametric test. The requirement of paramatric test, firstly interval data, secondly normal distribution. But, in our research, the data didn't need the criteria of normality. So, we use MannWhitney Test as a non parametric test. ${ }^{[12]}$

\section{RESULTS}

Mean scores of Kaempferia galanga extract in 3 different solvents are: Kaempferia galanga (dichlormethane) is 1.6400; Kaempferia galanga (ethanol) is 1.7440 ; Kaempferia galanga extract is 1.6600; boiled Kaempferia galanga is 1.7000. Using Mann-Whitney Test as shown in the table 1, the results are: negative controls have no inhibition effect on Lactobacillus acidophilus compaired to Kaempferia galanga, comparation of those 4 Kaempferia galanga treatments shows no significant difference, those 4 Kaempferia galanga treatments compaired to erythromycin antibacterial effect shows significant difference, otherwise 4 Kaempferia galanga treatments compaired to penicillin shows no significant difference except Kaempferia galanga (ethanol). 
Table 1. Experimental result of Kaempferia galanga toward Lactobacillus acidophilus

Kaempferia galanga

Inhibition zone (cm)

\begin{tabular}{lccccc}
\hline & $\begin{array}{c}\text { Repeated } \\
\text { test 1 }\end{array}$ & $\begin{array}{c}\text { Repeated } \\
\text { test 2 }\end{array}$ & $\begin{array}{c}\text { Repeated } \\
\text { test 3 }\end{array}$ & $\begin{array}{c}\text { Repeated } \\
\text { test 4 }\end{array}$ & $\begin{array}{c}\text { Repeated } \\
\text { test 5 }\end{array}$ \\
\hline $\begin{array}{l}\text { Kaempferia galanga extract } \\
\text { (dichlormethane) }\end{array}$ & 1,52 & 1,6 & 1,8 & 1,48 & 1,8 \\
$\begin{array}{l}\text { Kaempferia galanga extract } \\
\text { (etanol) }\end{array}$ & 1,7 & 1,6 & 1,8 & 1,82 & 1,8 \\
Kaempferia galanga extract & 1,6 & 1,8 & 1,7 & 1,6 & 1,6 \\
Boiled Kaempferia galanga & 1,8 & 1,8 & 1,7 & 1,7 & 1,5 \\
Penicillin & 1,5 & 1,62 & 1,5 & 1,62 & 1,64 \\
Erithromycine & 3,4 & 3,5 & 3,5 & 3,52 & 3,4 \\
Dichlormethane blanco & 0 & 0 & 0 & 0 & 0 \\
Ethanol blanco & 0 & 0 & 0 & 0 & 0 \\
Aquades blanco & 0 & 0 & 0 & 0 & 0 \\
\hline
\end{tabular}

Table 2. Statistical Experimental Result

\begin{tabular}{cccccc}
\hline & N & Mean & St.Deviasi & \multicolumn{2}{c}{$95 \% \mathrm{Cl}$} \\
\cline { 5 - 6 } & & & & Lower & Upper \\
\hline KGL Dichlormethane & 5 & 1.6400 & 0.1523 & 1.4509 & 1.8291 \\
KGL ethanol & 5 & 1.7440 & 0.0932 & 1.6283 & 1.8597 \\
KGL extract & 5 & 1.6600 & 0.0894 & 1.5489 & 1.7711 \\
KGL boiled & 5 & 1.7000 & 0.1225 & 1.5479 & 1.8521 \\
Penicillin & 5 & 1.5760 & 0.0699 & 1.4893 & 1.6627 \\
Erithromicyn & 5 & 3.4640 & 0.0590 & 3.3908 & 3.5372 \\
Dichlormethane & 5 & 0.0000 & 0.0000 & 0.0000 & 0.0000 \\
Etanol & 5 & 0.0000 & 0.0000 & 0.0000 & 0.0000 \\
\hline Total & 40 & 1.4730 & 1.0471 & 1.1381 & 1.8079 \\
\hline
\end{tabular}

According to Mann-Whitney Test $: p<0,005$ indicates significant difference, $p>0,005$ indicates no significant difference. The results are :

a. Kaempferia galanga dichlormethane : penicillinis 0,752 , indicates no significant difference

b. Kaempferia galanga ethanol : penicillinis 0,045 , indicates significant difference

c. Kaempferia galanga extract : penicillin is 0,456 , indicates no significant difference

d. Kaempferia galanga boiled : penicillinis 0,070 , indicates no significant difference e. Kaempferia galanga dichlormethane : erithromicyn is 0,008 , indicates significant difference

f. Kaempferia galanga ethanol : erithromicyn is 0,008 , indicates significant difference

g. Kaempferia galanga extract :erithromicyn is 0,008 , indicates significant difference

h. Kaempferia galanga boiled : erithromicyn is 0,008 , indicates significant difference 


\section{DISCUSSION}

From the above empirically and laboratories studies indicates that Kaempferia galanga might be useful for preventing dental cavities. In this research there are three kinds of antibacterial substances were extracted by dichlormethane, ethanol, and aquades. These substances possess efficient antibacterial activities against Streptococcus spp., Actinomyces spp., and Lactobacillus spp. ${ }^{[13] .}$

Dichlormethaneand ethanol can draw lenthionine substance in Kaempferia galanga extract, while distilled water can draw lentinan substance. ${ }^{[13]}$ As a medium of inoculum bacteri Lactobacillus acidophilusthis researchused MRS agar (de Man, Rogosa, Sharpe), because the MRS formulation can provide a medium which would support good growth of lactobacilli in general, even those strains which showed poor growth in existing media. MRS Agar and Broth were designed to encourage the growth of the "lactic acid bacteria" which includes species of the following genera Lactobacillus. All these species can produce lactic acid in considerable amounts. Generally the "lactic acid bacteria" show delayed growth and smaller colony size than other microorganisms. They may be overgrown in non-selective media, especially if incubation is required for 2-4 days. Selection can be made by $\mathrm{pH}$ adjustment, thus lactobacilli will tolerate lower $\mathrm{pH}$ levels than streptococci $(\mathrm{pH}$ 5.0-6.5). An evaluation of media for selective enumeration of Lactobacillus acidophilus. In the prescence of other lactic acid bacteria which are present in yoghurt. The Lactobacilli are micro aerophillic and generally require layer plates for aerobics cultivation on solid media. Submerged or surface colonies may be compact or feathery, and are small, opaque and white. In this research penicillin and erythromycin as a control positive, because penicillin has broad spectrumwhich effective against gram possitive organism such as Lactobacillus acidophilus and some gram negative cocci. ${ }^{[14],[15],[2]}$ Mann-Whitney test isused to know the mean differences between treatment and control group in this research. Kaempferia galanga has the antibacterial effect which can kill the bacteria known as "bacteriosid". It was shown that in a view days later after the experiments the inhibition zone was not overgrown by the Lactobacillus acidophilus.

\section{CONCLUSIONS}

This research shows that Kaempferia galanga extract has antibacterial effect toward Lactobacillus acidophilus(shown in table 2 and figure 4) and it can kill the bacteria. Therefore Kaempferia galanga extract in ethanol has the strongest factor to kill Lactobacillus acidophilus. But we should take our consideration that ethanol has a toxic nature, therefore we can use only the Kaempferia galanga extract in a larger dose. And the Kaempferia galanga extracts showed better antibacterial activity than penicillin (shown in table 2).

\section{REFERENCE}

1. http://en.wikipedia.org/wiki/Caries

2. Macmillan, C. The Pharmacological Basis of Therapeutics. $4^{\text {th }} \mathrm{Ed}$. The Macmillan Company. London. 1209

3. Schuster, George S. (tahun). Oral Microbiology and Infectious Disease, $2^{\text {nd }} E d$. Williams \& Wilkins. Baltimore, London. 202-209. 2-1

4. http://www.yourreturn.org/Treatments/ Teeth/Lactobacillusacidophilus.gif

5. http://images.encarta.msn.com/xrefm edia/sharemed/targets/images/pho/t2 42/T242281A.jpg

6. http://oegeng.blogspot.com/2008/01/K aempferia galanga-untukkolesterol.html 
7. id-wikipedia.org

8. http://www.litbang.deptan.go.id/tahuka $h-a n d a / ? p=7$

9. http://cybermed.cbn.net.id/cbprtl/cyber med/detail.aspx? $x=$ Natural+Healing \& $\mathrm{y}=$ cybershopping $|8| 0|3| 147$

10. http://commons.wikimedia.org/wiki/

11. http://bahanalam.fa.itb.ac.id/detail.php?id=210\#to $p$

12. Fallik Brown. (1983). Statistics. The Dorsey Press. for Behavioral Sciences

13. International Journal of Antimicrobial Agents II (1999) 151-157

14. Francis, L.E. (1961). Dental Pharmacology and Therapeutics.W.B.Saunders Company. Philadelphia. 117

15. Ciancio, S.G. Clinical Pharmacology for Dental Profrssionals. $2^{\text {nd }}$ Ed. PSG Publishing Company, Inc. Massachusetts 52 